\title{
KAJIAN DEGRADASI LAHAN SEBAGAI DASAR PENGENDALIAN BANJIR DI DAS JUWANA
}

\author{
Arina Miardini' ${ }^{1}$, Totok Gunawan ${ }^{2}$, dan Sigit Heru Murti ${ }^{3}$
}

Kementrian Agraria dan tata Ruang, BPN RI ${ }^{1}$, Fakultas Geografi, Universitas Gadjah Mada, Yogyakarta Indonesia ${ }^{2,3}$ arinamiardini@gmail.com

Diterima : Desember 2015 ; Direvisi : Juni 2016; Dipubikasikan: September 2016

\begin{abstract}
ABSTRAK Adanya pemanfaatan lahan yang intensif dan ekspolitatif dapat menurunkan daya dukung dan fungsi lingkungan DAS yang menyebabkan lahan menjadi terdegradasi. Tingginya luasan lahan kritis menjadi ancaman terhadap daya dukung DAS yang akan berdampak pada ketidakseimbangan hidrologi dalam DAS. Salah satu akibat ketidakseimbangan hidrologi dalam DAS adalah terjadinya banjir. DAS Juwana merupakan DAS Prioritas I berdasarkan penetapan 108 DAS prioritas. Salah satu indikator untuk menentukan degradasi dalam DAS dapat diketahui berdasarkan nilai koefisien aliran. Penelitian ini bertujuan untuk mengidentifikasi karakteristik fisik DAS yang berpengaruh dalam penentuan koefisien aliran, menghitung koefisien aliran dengan mempertimbangkan parameter karakteristik fisik DAS dan memberikan rekomendasi pengelolaan banjir di DAS Juwana yang potensial banjir dalam mendukung upaya pengelolaan DAS dari hulu sampai hilir. Koefisien aliran dihitung denggan menggunakan metode cook yang memperhitungkan parameter kemiringan lereng, infiltrasi tanah, tutupan vegetasi dan simpanan permukaan. Perumusan pengendalian banjir dilakukan dengan melakukan penatagunaan lahan yang disesuaikan dengan arahan fungsi penggunaan lahan sehingga diharapkan menurunkan nilai koefisien aliran dan debit banjir. Karakteristik fisik DAS Juwana yang mempengaruhi penentuan koefisien aliran berdasarkan metode Cook yaitu Kemiringan lereng dengan rata-rata skor C sebesar 0,178 , kerapatan aliran dengan rata-rata skor 0,084 , infiltrasi dengan rata-rata skor 0,115 dan tutupan vegetasi dengan rata-rata skor 0,127. Kontribusi masing masing parameter dalam penilaian koefisien aliran yang memiliki pengaruh paling terbesar sampai paling terkecil dalam besarnya koefisien aliran yaitu kemiringan lereng yang memiliki pengaruh sebesar 35,39\%, kemudian tutupan vegetasi sebesar $25,25 \%$, infiltrasi sebesar 22,86\% dan terakhir adalah kerapatan aliran yang berkontribusi sebesar 16,70\%. Nilai koefisien aliran di DAS Juwana sebesar 50,25\% yang termasuk kriteria tinggi. Daerah yang menjadi prioritas penanganan dalam pengendalian banjir terdapat pada satuan lahan yang memiliki nilai koefisien aliran tinggi sampai ekstrim seluas 48042,46 ha atau sebesar 36,84\% dari luas DAS Juwana. Dalam upaya mengendalikan banjir dirumuskan beberapa pengelolaan yaitu penatagunaan lahan merestorasi, reklamasi dan konservasi penggunaan lahan sesuai dengan arahan fungsi penggunaan lahan sehingga dapat dikendalikannya aliran permukaan (surface run-off) karena berfungsinya tutupan vegetasi pada setiap penggunaan lahan disertai dengan pengelolaan lahan yang berbasis konservasi tanah dan air serta melalui pendekatan kolaboratif dengan memperhatikan potensi dan sensitivitas sumberdaya dalam DAS dan pesisir sehingga diperoleh pengelolaan yang terpadu.
\end{abstract}

Kata kunci: banjir; DAS Juwana; degradasi lahan; Metode Cook.

ABSTRACT Intensive and exploitative land use has a propensity to decline the watershed carrying capacity and environmental function which leads to the increasing number of land degradation. The vast area of critical land was evidenced to be a serious threat for watershed carrying capacity which eventually affected the hydrology imbalance in the watershed area. As the consequence, the flood frequently occurred. Juwana watershed is classified as Watershed Priority I based on the determination of 108 watersheds priority. One among the indicators to determine the degradation level in the watershed could be figured out from the value of runoff coefficient. The study was aimed to identify the watershed physical characteristics of which affect the determination of runoff coefficient, to calculate the runoff coefficient by assessing the parameter of watershed physical characteristics and to provide recommendations concerning with flood management system, particularly in flood susceptibility areas of Juwana watershed in order to support watershed management system of the upstream to downstream areas. Runoff coefficient was calculated by the Cook's Method by evaluating the parameters of slope steepness, soil infiltration, vegetation cover, and surface deposits. The physical characteristics of Juwana watershed affecting the determination of runoff coefficient based on Cook's method were slope steepness with the average $C$ score of 0.178 , drainage density with the average score of 0.084 , infiltration with the average score of 0.115 and vegetation cover wit the average score of 0.127 . The contribution or each parameter in the assessment of runoff coefficient, from the highest to the smallest contribution in the value of runoff coefficient, respectively, slope steepness of $35.39 \%$, vegetation cover of $25.25 \%$, infiltration of $22.86 \%$ and drainage density of $16.70 \%$. The value of runoff coefficient of Juwana watershed was $50.25 \%$ and it can be classified as high. Area turning out to be flood control priority are the land unit with high to extreme runoff coefficient value of 48042.46 ha or as much as $36.84 \%$ of Juwana watershed areas. The flood control in Juwana watershed is formulated in several points ranging from land use planning, restoration, reclamation, and conservation in accordance to the guideline of land use function, hence, surface runoff can be controlled since the function of vegetation cover in each land use is accompanied by land management based on soil and water conservation through collaborative approach with particular consideration on the potency and sensitivity of resources in the watershed and coastal areas to obtain a integrated watershed management.

Key words: flood; Juwana Watershed; land degradation; Cook Method. 


\section{PENDAHULUAN}

Daerah Aliran Sungai (DAS) merupakan satu kesatuan ekosistem yang terdiri dari hulu sampai hilir dengan komponen penyusun ekosistemnya, termasuk di dalamnya sumberdaya lahan. Adanya pemanfaatan lahan yang intensif dan ekspolitatif dapat menurunkan daya dukung dan fungsi lingkungan DAS yang menyebabkan lahan menjadi terdegradasi. Proses degradasi lahan mengalami kecenderungan meningkat dari tahun ke tahun yang ditandai dengan makin meningkatnya luasan lahan kritis yang akan berdampak pada ketidakseimbangan hidrologi dalam DAS.

Salah satu akibat ketidakseimbangan hidrologi dalam DAS adalah terjadinya banjir. Banjir merupakan indikator kerusakan DAS yang disebabkan oleh menurunnya infiltrasi akibat berkurangnya penutupan vegetasi dan ketidaksesuaian penggunaan lahan (Sinukaban, 2007). Perubahan tata guna lahan dalam DAS merupakan salah satu penyebab peningkatan kejadian banjir terutama banjir limpasan. Banjir akan menjadi bencana jika bersifat merusak dan mengakibatkan kerugian jiwa dan material sehingga perlu dilakukan upaya pengelolaan banjir untuk mengurangi risiko banjir.

Kementerian Kehutanan melalui SK.328/Menhut-

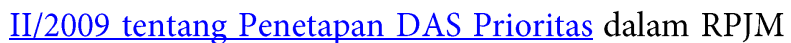
tahun 2010-2014 menyatakan bahwa terdapat 108 DAS yang termasuk dalam prioritas penanganan yang salah satunya yaitu DAS Juwana. Permasalahan yang muncul di DAS Juwana adalah terjadinya peningkatan lahan kritis yang berdampak pada peningkatan frekuensi banjir di DAS Juwana.

Banjir yang makin meningkat diduga diakibatkan oleh degradasi lahan yang menyebabkan tidak berfungsinya tutupan lahan bervegetasi di DAS Juwana terutama di hulu DAS Juwana sehingga menyebabkan banjir limpasan. Berdasarkan Peta Kawasan Hutan dari data Kementerian Kehutanan (2011), bahwa luas kawasan hutan di wilayah DAS Juwana belum memenuhi luas minimal yaitu memiliki luas kawasan hutan 14,17 \% dari luas DAS. Pada UU 41 tahun 1999 mengamanatkan bahwa pemerintah menetapkan dan mempertahankan kecukupan luas kawasan hutan dan penutupan hutan untuk setiap daerah aliran sungai, dan atau pulau guna optimalisasi manfaat lingkungan, manfaat sosial, dan manfaat ekonomi masyarakat setempat yaitu minimal 30\% dari luas DAS atau pulau dengan sebaran yang proporsional. Penelitian ini bertujuan untuk 1)mengidentifikasi karakteristik fisik DAS yang berpengaruh dalam penentuan koefisien aliran, 2)menghitung koefisien aliran dengan mempertimbangkan parameter karakteristik fisik DAS , dan 3)memberikan rekomendasi pengelolaan banjir di DAS Juwana yang potensial banjir dalam mendukung upaya pengelolaan DAS dari hulu sampai hilir.

\section{METODE PENELITIAN}

Penelitian dilakukan di DAS Juwana pada Bulan September 2014 sampai Februari 2015. Secara geografis DAS Juwana berada pada posisi koordinat antara $110^{\circ}$ $49^{\prime} 10^{\prime \prime}-111^{\circ} 12^{\prime} 57^{\prime \prime}$ BT dan antara $6^{\circ} 36^{\prime} 48^{\prime \prime}-6^{\circ} 59^{\prime}$ $29^{\prime \prime}$ LS. DAS Juwana merupakan DAS lintas kabupaten dalam propinsi (terdiri dari 52 kabupaten dalam propinsi Jawa Tengah).

Bahan yang digunakan dalam penelitian ini antara lain: Peta Batas DAS Juwana,data curah hujan harian series 10 tahun, data digital citra Landsat 8 tahun 2014 Path/row 120/65 resolusi spasial 30 x 30 m, peta Rupa Bumi Digital skala 1:25000, Peta jenis tanah skala 1:250000, Peta Kawasan hutan, Peta Arahan Fungsi Penggunaan Lahan. Peralatan yang diperlukan antara lain Notebook ASUS Core i3 kapasitas RAM 6 GB dan harddisk 500 GB Software Arc GIS 10.1 Software Ms.Word dan Ms. Excel GPS Garmin 60 CSX Abney level Double ring infiltrometer Gelas ukur dan stop watch dan kamera digital.

Metode pendugaan koefisien aliran yang digunakan dalam penelitian ini adalah Metode Cook. Chow (1964) dan Meijerink (1970) menduga limpasan permukaan melalui koefisien aliran dengan mempertimbangkan karakteristik DAS yaitu kemiringan lereng, infiltrasi tanah, tutupan vegetasi dan simpanan permukaan.

Unit análisis yang digunakan dalam penelitian adalah satuan lahan Meijerink (1970) dalam Gunawan (1991) menyatakan bahwa satuan lahan sebagai satuan interpretasi dan satuan pemetaan kenampakan bentang lahan terpilih yang dihubungkan dengan proses hidrologi. Peta satuan lahan merupakan hasil overlay dari peta bentuk lahan, kemiringan lereng dan penggunaan lahan (Gambar 1).

Penentuan sampel dilakukan secara secara stratified purposive sampling dengan intensitas sampling 5\%. Pada tahap lapangan mendatangi satuan lahan terpilih sebagai sampel kemudian dicatat kondisi lapangannya berupa koordinat lokasi, liputan kondisi sekitar dengan dokumentasi, cheking tutupan lahan, dan kemiringan lereng, penentuan tekstur tanah dan pada setiap perbedaan tekstur dilakukan uji infiltrasi. Cara penentuan skor baru untuk masing-masing kelas dari masing-masing faktor adalah sebagai berikut Gunawan (1991):

1. Nilai skor masing-masing kelas (i) pada suatu factor (j) adalah : 
Skor Kelas (i) faktor $(j)=\frac{\text { Lwas Kelas (ai } 1)}{\text { Lwas DAS }} x$ skor ilj

Total skor kelas $(i)=\sum_{i=1}^{n} \quad$ Skor Kelas $(i)$ faktor $(j)$

2. Total nilai skor dari seluruh kelas (i) untuk seluruh faktor $(j)$ adalah :

Total skor seluruh kelas (i) seluruh faktor $=(j)$ $\sum_{i=1}^{n} \sum_{j=1}^{m}$ total skor kelas (i) faktor $(j)$

Nilai koefisien aliran kemudian diklasifikasikan berdasar metode Cook yang dibagi menjadi 4 kelas yang dapat dilihat pada Tabel 1.

Degradasi lahan ditandai dengan adanya besarnya nilai koefisien aliran yang $>50 \%$. Prinsip pengendalian banjir limpasan di DAS Juwana didasarkan pada pengendalian nilai koefisien aliran Singh dan Mishra (2012) bahwa untuk menganalisis tutupan lahan bervegetasi pada dampak kejadian banjir pada masing-masing sub DAS difokuskan pada dua variabel yaitu tutupan vegetasi/lahan bervegetasi dan koefisien aliran. Simulasi dilakukan melalui penatagunaan lahan yang disesuaikan dengan peta arahan penggunaan lahan yang telah ada.

\section{HASIL DAN PEMBAHASAN}

\section{Karakteristik DAS yang Mempengaruhi Limpasan}

Berdasarkan hasil analisis terdapat 168 satuan lahan di DAS Juwana yang terdiri dari 2240 poligon. Satuan lahan ini akan menjadi unit analisis dan faktor pembobot dalam penilaian koefisien aliran. Untuk penentuan sampel dilakukan secara Stratified Purposive Sampling dengan intensitas 5\% sehingga jumlah sampel yang diamati sebanyak 112 titik.

\section{Kemiringan Lereng}

Nilai kemiringan tertinggi di DAS Juwana yaitu $55.58 \%$ dan terendah $0 \%$ dengan rata-rata kemiringan $6.68 \%$. Nilai kemiringan di DAS Juwana didominasi oleh kelas kemiringan datar (0-5\%) sebesar 68,92\% dari luas DAS Juwana (Tabel 2). Kondisi kemiringan lereng DAS Juwana yang didominasi kelas kemiringan lereng datar memiliki peluang degradasi lahan yang rendah karena kemiringan yang datar akan memperlambat aliran permukaan.

\section{Tutupan vegetasi}

Penggunaan lahan di DAS Juwana meliputi 11 jenis penggunaan lahan. Penggunaan lahan di DAS Juwana di dominasi oleh sawah irigasi sebesar $46,66 \%$ dari luas DAS Juwana. Persawahan tersebar luas pada Kecamatan Undaan, Majebo, Sukolilo, Jekulo, Gabus, Margorejo, Kayen, Pati, Jakenan, Wedarijaksa dan sebagian Juwana. Penggunaan lahan lain yang memiliki proporsi besar setelah sawah yaitu Pemukiman sebesar $14,05 \%$ dari luas DAS Juwana (Tabel 3).

Pemukiman tersebar hampir merata pada seluruh kelerengan mulai datar sampai agak curam. Jenis pemukiman berupa rumah semi permanen sampai permanen dengan dinding batu bata. Penggunaan lahan ketiga yaitu tegalan sebesar $13,30 \%$ dari luas DAS. Tegalan di DAS Juwana merupakan lahan kering yang letaknya terpisah dengan pemukiman biasanya ditanami tanaman semusim dengan proporsi yang lebih besar dibandingkan tanaman berkayu maupun tahunan. Tutupan lahan diklasifikasikan menjadi 4 kelas yaitu tidak ada vegetasi (0\%), sedikit vegetasi $(>0-10 \%)$, sedang $(>10-80 \%)$ dan vegetasi rapat $(>80 \%)$ disajikan pada Tabel 4 .

Tabel 1. Klasifikasi Limpasan

\begin{tabular}{lll}
\hline Kelas & Kriteria & Nilai $(\%)$ \\
\hline I & Rendah & $<25$ \\
II & Normal & $25-50$ \\
III & Tinggi & $50-75$ \\
IV & Ekstrim & $75-100$ \\
\hline
\end{tabular}

Sumber : Meijerink (1970)

Tabel 2. Kemiringan Lereng DAS Juwana

\begin{tabular}{ccccc}
\hline No & Kelas Kemiringan Lereng & Kriteria & Luas (ha) & Prosentase (\%) \\
\hline 1 & $0-5 \%$ & Datar & 89846,87 & 68,92 \\
2 & $5-10 \%$ & bergelombang & 9868,81 & 7,57 \\
3 & $10-30 \%$ & Perbukitan & 23281,12 & 17,85 \\
4 & $>30 \%$ & Terjal & 7394,52 & 5,66 \\
& Jumlah & & 130391,3 & 100 \\
\hline
\end{tabular}

Sumber : Hasil Analisis Kontur RBI Skala 1:25.000 dan Checking Lapangan (2014) 


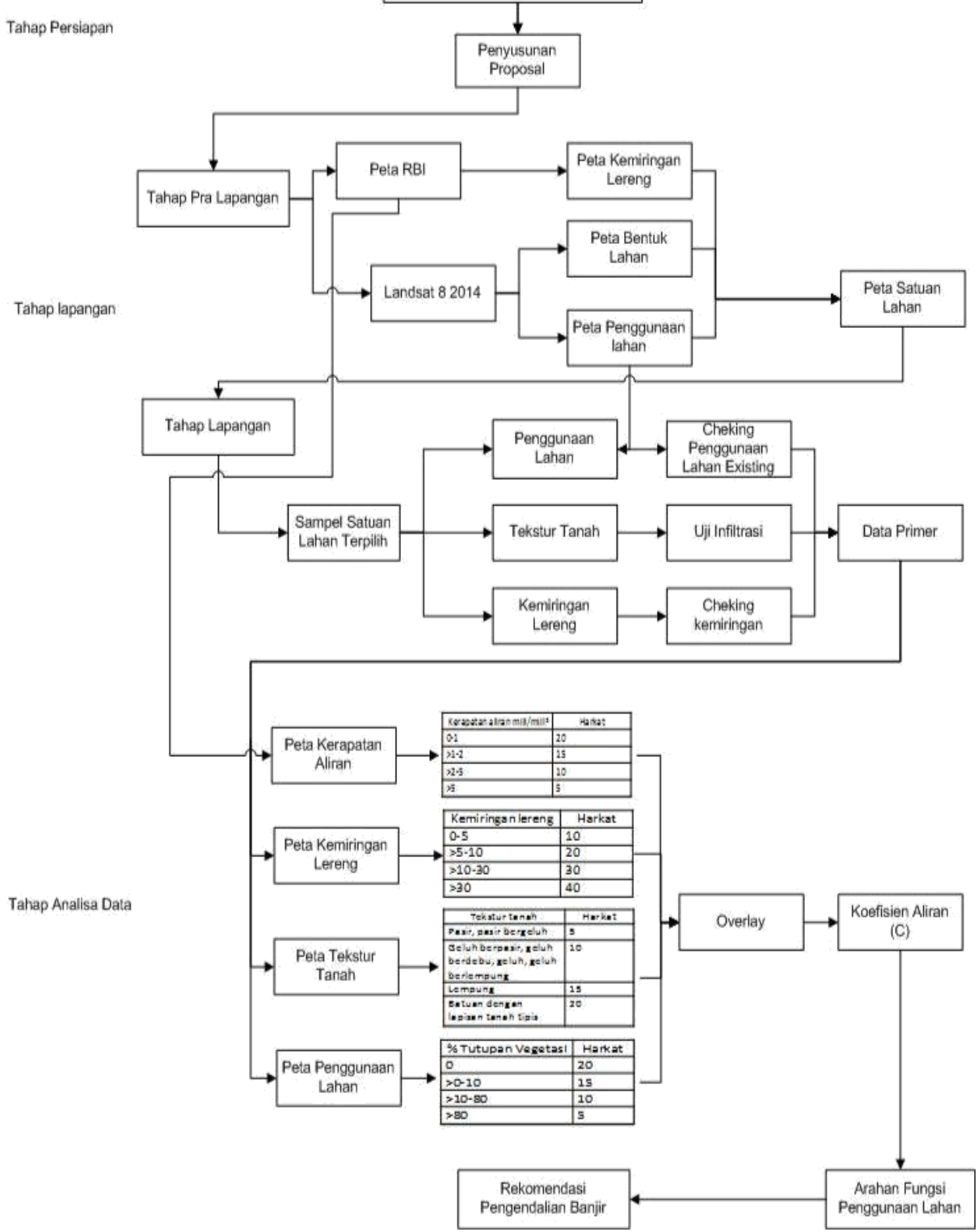

Gambar 1. Bagan Alir Penelitian

Tabel 3. Penggunaan Lahan di DAS Juwana

\begin{tabular}{clrr}
\hline No & Tutupan Lahan & Luas (ha) & Prosentase( \%) \\
\hline 1 & Air Laut & 51,55 & 0,04 \\
2 & Air Tawar & 355,54 & 0,27 \\
3 & Belukar/semak & 3257,02 & 2,5 \\
4 & Hutan & 1599,46 & 1,23 \\
5 & Kebun & 14026,74 & 10,76 \\
6 & Pemukiman & 18319,4 & 14,05 \\
7 & Rumput & 262,42 & 0,2 \\
8 & Sawah Irigasi & 60845,15 & 46,66 \\
9 & Sawah Tadah Hujan & 10884,29 & 8,35 \\
10 & Tambak & 3448,07 & 2,64 \\
11 & Tegalan & 17341,69 & 13,3 \\
& Jumlah & 130391,3 & 100 \\
\hline
\end{tabular}

Sumber : Hasil Pengolahan dan Analisis Data (2014) 
Tabel 4. Tutupan Vegetasi di DAS Juwana

\begin{tabular}{cllcc}
\hline No & Tutupan Vegetasi (\%) & Kriteria & Luas (ha) & Prosentase \\
\hline 1 & $0 \%$ & tidak ada vegetasi & 25403,92 & 19,48 \\
2 & $(>0-10 \%)$ & sedikit vegetasi & 28395,57 & 21,78 \\
3 & $(>10-80 \%)$ & Sedang & 61237,87 & 46,96 \\
4 & $(>80 \%)$ & vegetasi rapat & 15353,97 & 11,78 \\
& $\quad$ Jumlah & & 130391,3 & 100 \\
\hline
\end{tabular}

Sumber : Pengolahan dan Analisis Data (2015)

\section{Kerapatan Aliran}

DAS Juwana secara umum didominasi oleh kerapatan aliran normal dengan luasan sebesar 48,68\%. Kerapatan aliran yang normal memungkinkan aliran permukaan dari wilayah diatas anak anak sungai untuk terdrainase sehingga air hujan akan terbagi dan akan mengurangi debit puncak. DAS Juwana memiliki sungai-sungai dengan banyaknya percabangan yang akan memberikan reaksi lebih cepat terhadap masuknya curah hujan sehingga kecepatan aliran permukaan juga lebih tinggi. Kerapatan aliran juga memiliki pengaruh terhadap waktu konsentrasi (Tabel 5).

Berdasarkan hasil penentuan tekstur dari sampel tanah di lapangan terdapat 7 kelas tekstur tanah di DAS Juwana. DAS Juwana didominasi oleh tanah dengan tekstur geluh lempung pasiran (SCL) yaitu sebesar $42,86 \%$ dengan laju infiltrasi sedang. Tekstur lempung debuan $(\mathrm{SiC})$ dan geluh lempung debuan (SiCL) juga mendominasi tekstur tanah di DAS Juwana sebesar $17,8 \%$ dan $16,25 \%$ (Tabel 6). Komponen tekstur yang dominan di DAS Juwana berupa geluh dan lempung. Tanah geluh di DAS Juwana banyak terdapat di tanah-tanah budidaya. Pada 7 kelas tekstur tersebut dilakukan pengukuran nilai infiltrasi pada masing-masing tekstur. Laju infiltrasi di DAS Juwana berkisar antara lambat sampai sedang dengan nilai antara $6,948 \mathrm{~mm} /$ jam sampai 24,004 mm/jam.

\section{Pendugaan Koefisien Aliran}

Nilai koefisien aliran DAS Juwana berdasarkan hasil perhitungan dalam metode Cook yaitu sebesar $50,25 \%$ yang tergolong kriteria tinggi. DAS Juwana didominasi oleh nilai limpasan dengan kriteria normal sebesar 63,15\% dari luas DAS Juwana. Kisaran nilai koefisien aliran tinggi sampai ekstrim terdapat pada sungai yang berhulu di Gunung Muria, sedangkan pada sungai yang berhulu di Pegunungan Kendeng masih dalam kisaran normal sampai tinggi. Hasil analisis limpasan berdasarkan metode Cook ditunjukkan pada Tabel 7 dan Gambar 2.

Daerah yang menjadi prioritas penanganan dalam pengendalian banjir terdapat pada satuan lahan yang memiliki nilai koefisien aliran tinggi sampai ekstrim seluas 48042,46 ha atau sebesar $36,84 \%$ dari luas DAS Juwana. Kontribusi masing masing parameter dalam penilaian koefisien aliran dalam besarnya koefisien aliran yaitu kemiringan lereng yang memiliki pengaruh sebesar 35,39\%, kemudian tutupan vegetasi sebesar $25,25 \%$, infiltrasi sebesar $22,86 \%$ dan terakhir adalah kerapatan aliran yang berkontribusi sebesar $16,70 \%$. Nilai kontribusi masing-masing parameter ini akan menentukan pilihan strategi pengendalian banjir di DAS Juwana. Kontribusi parameter pada masingmasing dapat dilihat pada Tabel 8.

\section{Pengendalian Banjir}

Peningkatan frekuensi banjir di DAS Juwana merupakan salah satu indikator ketidakberhasilan pengelolaan DAS. Salah satu tujuan pengelolaan DAS adalah untuk mengendalikan banjir dan mengatur hasil air baik dari segi kuantitas, kualitas maupun kontinyuitas. Dengan meningkatnya luas lahan terbuka akan meningkatkan nilai koefisien aliran berarti prosentase air hujan yang menjadi limpasan (air permukaan) menjadi lebih besar. Peningkatan volume air permukaan dalam konteks hidrologi DAS menunjukkan kesehatan DAS cenderung memburuk. Artinya semakin tinggi aliran permukaan maka potensi air yang meresap ke dalam tanah berkurang, dan sebaliknya peluang bencana banjir akan meningkat karena meningkatnya aliran permukaan. Upaya pengendalian banjir di DAS Juwana dapat dilakukan melalui empat hal yaitu:

a. Penatagunaan lahan

Tujuan dilakukan penatagunaan lahan adalah diperolehnya kesesuaian Penggunaan lahan dengan arahan fungsi penggunaan lahan melalui beberapa program antara lain: 1) Penataan kembali penggunaan lahan yang ada berdasarkan kesesuaian arahan fungsi penggunaan lahan, 2) Pengendalian alih fungsi lahan hutan menjadi lahan non hutan.

b. Rehabilitasi hutan dan lahan

Tujuan pada strategi ini yaitu; 1) Mengembalikan fungsi hutan lindung dan hutan produksi sebagai ruang terbuka hijau yang berperan sebagai pengatur tata air., 2) Rehabilitasi fungsi kawasan lindung diluar hutan yg diarahkan sebagai pengatur tata air 
dan produksi. 3) Rehabilitasi lahan pada kawasan budidaya yg diarahkan guna pengendalian aliran permukaan dan peningkatan fungsi produksi.

c. Konservasi tanah dan air

Strategi ini bertujuan untuk mengurangi dan menurunkan laju aliran permukaan dengan sasaran pada ahan dengan kemiringan berbukit sampai terjal yang belum menerapkan konservasi tanah dan air baik konservasi tanah dan air secara vegetative maupun konservasi tanah dan air sipil teknis

d. Pengelolaan DAS terpadu

Tujuan pengelolaan DAS terpadu di DAS Juwana yaitu mewujudkan penataan wilayah DAS dan pesisir Juwana yg terintegrasi antar wilayah, antar sektor dan antar pemangku kepentingan. Kegiatan pada program ini antara lain : 1) mengembangkan kerjasama antar wilayah, sektor \& pemangku kepentingan Kab/ Kota dalam pengelolaan DAS Juwana, 2) koordinasi lintas sektor dan dengan lembaga non formal lainnya, dan 3) pengembangan
SDM melalui pelatihan staf, pelatihan kelompok tani, dll.

Tabel 5. Kerapatan Aliran di DAS Juwana

\begin{tabular}{|c|c|c|c|c|}
\hline No & $\begin{array}{l}\text { Kerapatan } \\
\text { aliran } \\
\left(\mathrm{mill} / \mathrm{mill}^{2}\right)\end{array}$ & Kriteria & $\begin{array}{l}\text { Luas } \\
\text { (ha) }\end{array}$ & $\begin{array}{c}\text { Prosentase } \\
(\%)\end{array}$ \\
\hline 1 & $0-1$ & Diabaikan & 7800,24 & 5,98 \\
\hline 2 & $>1-2$ & Rendah & 417,71 & 0,32 \\
\hline 3 & $>2-5$ & Normal & 63479,19 & 48,68 \\
\hline 4 & $>5$ & Tinggi & 58694,18 & 45,01 \\
\hline \multicolumn{3}{|c|}{ Jumlah } & 130391,21 & 100,00 \\
\hline
\end{tabular}

Sumber : Pengolahan dan Analisis Data (2015)

Tabel 7. Nilai Koefisien Aliran C Hasil Pendugaan dengan Metode Cook

\begin{tabular}{cclrr}
\hline No & $\begin{array}{c}\text { Nilai Koefisien } \\
\text { Aliran (\%) }\end{array}$ & Kriteria & $\begin{array}{c}\text { Luas } \\
\text { (ha) }\end{array}$ & $\begin{array}{c}\text { Prosentase } \\
(\%)\end{array}$ \\
\hline 1 & $>25-50$ & Normal & 82348,76 & 63,15 \\
2 & $>50-75$ & Tinggi & 45154,27 & 34,63 \\
3 & $>75$ & Ekstrim & 2888,19 & 2,21 \\
& Jumlah & & 130391,21 & 100,00 \\
\hline
\end{tabular}

Sumber : Pengolahan dan Analisis Data (2015)

Tabel 6. Laju Infiltrasi pada Masing-masing Tekstur Tanah di DAS Juwana

\begin{tabular}{cclcc}
\hline No & Kelas Tekstur & Nama Tekstur & Laju Infiltrasi $(\mathrm{mm} /$ jam$)$ & Kelas laju Infiltrasi \\
\hline 1 & $\mathrm{C}$ & Lempung & 6,948 & Lambat \\
2 & $\mathrm{CL}$ & Geluh Lempungan & 17,687 & Sedang \\
3 & $\mathrm{SC}$ & Lempung Pasiran & 6,317 & Lambat \\
4 & $\mathrm{SCL}$ & Geluh Lempung Pasiran & 24,004 & Sedang \\
5 & $\mathrm{SiC}$ & Lempung Debuan & 9,475 & Lambat \\
6 & $\mathrm{SiCL}$ & Geluh Lempung Debuan & 16,424 & Sedang \\
7 & $\mathrm{SiL}$ & Geluh Debuan & 20,845 & Sedang \\
\hline
\end{tabular}

Sumber : Pengolahan dan Analisis Data (2015)

Tabel 8. Kontribusi Karakteristik DAS terhadap Koefisien Aliran

\begin{tabular}{clccc}
\hline No & Karakteristik fisik DAS & Rata-Rata Skor C & Rata-Rata Koefisien Aliran (C) & Kontribusi Karakteristik Fisik DAS (\%) \\
\hline 1 & Kemiringan Lereng & 0,178 & 0,503 & 35,39 \\
2 & Tutupan Vegetasi & 0,127 & & 25,25 \\
3 & Infiltrasi & 0,115 & & 22,86 \\
4 & Kerapatan Aliran & 0,084 & 16,70 \\
\hline
\end{tabular}

Sumber : Pengolahan dan Analisis Data (2015) 


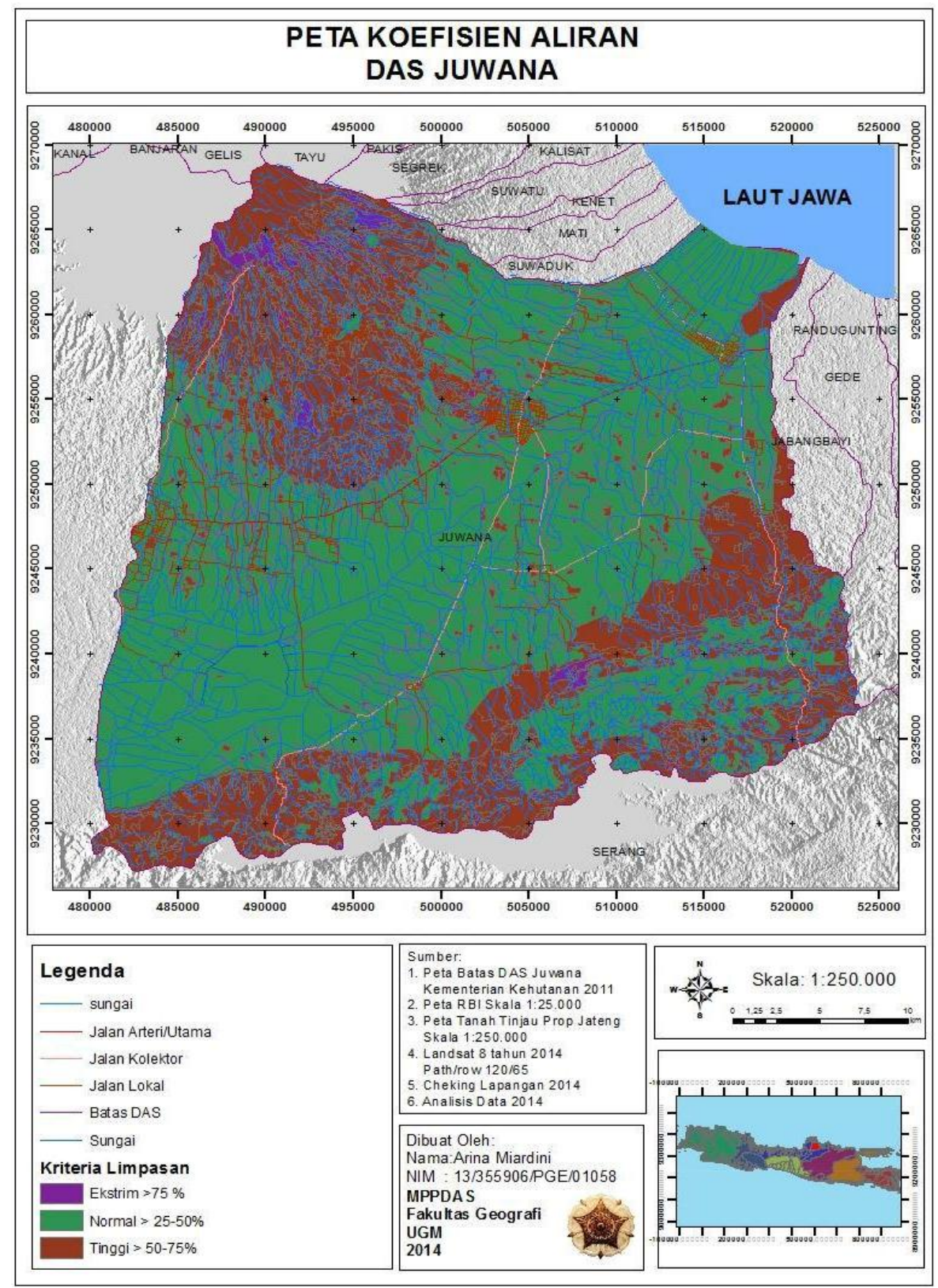

Gambar 2. Peta Koefisien Limpasan DAS Juwana

\section{KESIMPULAN}

1. Karakteristik fisik DAS Juwana yang mempengaruhi penentuan koefisien aliran berdasarkan metode Cook yaitu Kemiringan lereng dengan rata-rata skor $\mathrm{C}$ sebesar 0,178 , kerapatan aliran dengan rata-rata skor 0,084 , infiltrasi dengan rata-rata skor 0,115 dan tutupan vegetasi dengan rata-rata skor 0,127. Kontribusi masing masing parameter dalam penilaian koefisien aliran yang memiliki pengaruh paling terbesar sampai paling terkecil dalam besarnya koefisien aliran yaitu kemiringan lereng yang memiliki pengaruh sebesar $35,39 \%$, kemudian tutupan vegetasi sebesar $25,25 \%$, infiltrasi sebesar $22,86 \%$ dan terakhir adalah kerapatan aliran yang berkontribusi sebesar $16,70 \%$
2. Nilai koefisien aliran di DAS Juwana sebesar $50,25 \%$ yang termasuk kriteria tinggi. Daerah yang menjadi prioritas penanganan dalam pengendalian banjir terdapat pada satuan lahan yang memiliki nilai koefisien aliran tinggi sampai ekstrim seluas 48042,46 ha atau sebesar $36,84 \%$ dari luas DAS Juwana

3. Dalam upaya mengendalikan banjir di DAS Juwana dirumuskan beberapa pengelolaan yaitu penatagunaan lahan, merestorasi, reklamasi dan konservasi penggunaan lahan sesuai dengan arahan fungsi penggunaan lahan sehingga dapat dikendalikannya aliran permukaan (surface run-off) karena berfungsinya tutupan vegetasi pada setiap penggunaan lahan disertai dengan pengelolaan lahan yang berbasis konservasi tanah dan air http://jurnal.ugm.ac.id/mgi | 140 
melalui pendekatan kolaboratif dengan memperhatikan potensi dan sensitivitas sumberdaya dalam DAS dan pesisir sehingga diperoleh pengelolaan yang terpadu.

\section{DAFTAR PUSTAKA}

Ananda, J dan Proctor, W. (2012). Analysis Collaborative approaches to water management and planning: An institutional perspective. Journal Ecological Economics. 86, 97-106.

Asdak, C. (2004). Hidrologi dan Pengelolaan Daerah Aliran Sungai. Cetakan ketiga. Yogyakarta : Gadjah Mada University Press.

BPDAS Pemali Jratun. (2011). Rencana Pengelolaan DAS Terpadu Wilayah DAS Juana. Dirjen BPDASPS. Kementerian Kehutanan

Gunawan, T. (1991). Penerapan Tekhnik Penginderaan Jauh untuk Menduga Debit Puncak menggunakan Karakteristik Lingkungan Fisik DAS. Studi Kasus di Daerah aliran Sungai Bengawan Solo Hulu. Disertasi. Bogor : Fakultas Pascasarjana, Institut pertanian Bogor.

Meijerink, A. M. J. (1970) Photo Interpretation in Hydrology A Geomorphological Approach. ITC. Delf.

Paimin, Purwanto, D. dan R, Indrawati. (2012). Sistem Perencanaan Pengelolaan Daerah Aliran Sungai.
Bogor : Pusat Penelitian dan Pengembangan Konservasi dan Rehabilitasi (P3KR).

Seyhan, E. (1977). Fundamentals of Hydrology, (terjemahan) Subagyo. 1993. Dasar-Dasar Hidrologi. Cetakan kedua. Yogyakarta : Gajah Mada University Press.

Singh, S. \& A., Mishra. (2012). Spatiotemporal analysis of the effects of forest covers on water yield in the Western Ghats of peninsular India. Journal of Hydrology. 446-447, 24-34.

Sinukaban, N. (2007). Peranan Konservasi Tanah dan Air dalam Pengelolaan Daerah Aliran Sungai. Bunga Rampai Konservasi Tanah dan Air 20042007. Jakarta : Masyarakat Konservasi Tanah dan Air.

\section{Perundang-undangan}

Undang-Undang Nomor 41 Tahun 1999 tentang Kehutanan. Lembaran Negara Republik Indonesia Tahun 1999 Nomor 167. Jakarta : Sekretariat Negara.

Keputusan Menteri Kehutanan No. SK. 328/MenhutII/2009 Tentang Penetapan Daerah Aliran Sungai (DAS) Prioritas dalam Rangka Rencana Pengembangan Jangka Menengah (RPJM) tahun 2010-2014. Jakarta : Kementrian Kehutanan. 